\title{
Editorial: An Intelligent Communion? Episcopal Reflections Post Lambeth
}

\author{
Stephen Pickard, Associate Editor \\ spickard@adelaide.anglican.com.au
}

\section{Introduction: 'Come Let Us Reason Together'}

Lambeth 2008 was the fourteenth Lambeth gathering since the first one in 1867. Bishops and spouses from around the globe gathered for two and a half weeks of engagement through retreat, worship, bible study, indaba groups, forums and plenary sessions, not to mention eating, fringe events, marching through London calling for an end to poverty and the fulfilment of the Millennium Development Goals.

Lambeth 2008 was quite different from previous gatherings. The parliamentary style debate, motions, decisions and resolution process of 1968, 1978, 1988 and 1998 would not occur on this occasion. Instead, the accent would be on careful and sustained listening to each other through bible study and Indaba groups. Indaba is a Zulu word to describe what happens when a village comes together to discuss a problem.

The focus of the conference was the role of the bishop in the contemporary world. A variety of topics presented themselves for discussion: Anglican identity, evangelism and mission, poverty and HIV/ Aids, human sexuality, Covenant, other faiths, ecumenism. The real value of the Indaba groups and bible studies was in the relationships of trust the process forged across theological and cultural boundaries. The needs around the Communion are immense. One of the Burundi bishops in my bible study and Indaba group said 'a person with an empty stomach has no ears'. It was almost impossible to come away from Lambeth without an abiding sense of the richness and energy of the body of Christ. Our own struggles, conflicts and concerns were put in perspective in relation to stories of life in other places and cultures.

The life of a community of faith calls for more than cognition and debate, it calls for intelligent reasoning together and the engagement of the whole person as addressed by God. In Anglican life, ecclesial reasoning is undertaken in order to discern the truth of God. This requires judgments about good and evil (1 Kgs 3.1-15) and about the 
degree of importance to be accorded to the many concerns of the day. In Anglicanism, this process of truth-seeking has involved identifying fundamentals of faith and practice. The appeal to fundamentals belongs to the search for criteria in order to make wise judgments in controversial matters. In the contemporary Anglican Church, theologians have pointed to certain criteria to identify what might be regarded as an important issue calling for wider engagement. Both the search for fundamentals and identification of criteria to assist sound judgment have to do with ecclesial intelligence.

The recent Lambeth Conference also had something important to contribute to a shared life of reasoning together and the search for criteria for wise judgments. The essays in this volume of the Journal from participants at Lambeth offer some clues in this regard. As I read the essays I saw three themes emerging; prayer, learning and service. They represent gold threads in the Anglican weave and function as another set of criteria to make judgments about what might be termed the ecclesial intelligence of the body of Christ. The essays are both personal and theological.

The current edition of the Journal is the third of our special issues on the 2008 Lambeth conference, the previous ones pointing to our heritage of classic texts, and the role of theological education in the formation of national Anglican identity around the world. In the article that follows, I introduce the idea of spiritual and ecclesial intelligence and then consider the matter of fundamentals and criteria for judgments in the Church. The final section of the article discusses the various contributions from the Lambeth bishops, in terms of criteria for assessing the ecclesial and spiritual intelligence of the Communion.

\section{A Spiritually Intelligent Body?}

Can we Anglicans be an intelligent Communion? This is not a matter of IQ as such! In recent decades, the idea of intelligence has significantly broadened such that now it is more common to refer to 'multiple intelligences'. In this context, the concept of 'emotional intelligence' has become commonplace. Daniel Goleman and others have written on this subject and examined the conditions for 'the emotionally intelligent organization' and the kinds of leadership required for such an enterprise. ${ }^{1}$ There is a great deal within the social

1. See, for example, Daniel Goleman, Working with Emotional Intelligence (London: Blomsbury Publishing, 1998), Ch. 5; Daniel Goleman, Richard Boyatizs and Annie Mckee, The New Leaders: Transforming the Art of Leadership into the Science of Results (London: Little, Brown Publishing, 2002). 
sciences and organizational and behavioural literature that the Church of Jesus Christ might profitably take note of without necessarily becoming welded to the latest fad or theory. One of the key concepts that continually surfaces in such literature is the capacity for collaboration and teamwork. Goleman quotes a Japanese proverb, 'None of us are as smart as all of us' and he goes on to make the point that humans 'are the primordial team players: Our uniquely complex social relationships have been a crucial survival advantage. Our extraordinarily sophisticated talent for cooperation culminates in the modern organization'. ${ }^{2}$

The capacity for collaborative ventures does seem to be innate. Social philosopher Raimo Tuomela states that 'Cooperation seems to be innate, a coevolutionary adaptation based on group selection, the basic reason for this being that human beings have evolved in a group context'. ${ }^{3}$ Tuomela also notes the fact that people seem disposed to 'defect, act competitively, or even act aggressively'. The result is that we live in constant tension between these two elemental drives of cooperation and competition. However, within human societies, there seems to be an overriding emphasis upon competition; certainly in the West but in different ways throughout many cultures. The competitive spirit is deeply encoded into our way of life economically, socially, politically and, alas, religiously. Where competition rather than cooperation dominate the scene, it is axiomatic that power will be skewed in unhealthy ways.

In the life of the Anglican Communion, we see all too clearly the influence of the competitive spirit. The prevailing cultural values have a far greater impact on our religious life and leadership than most of us either realize, or care to know. Even more troubling is the remarkable ways, in which competition and misuse of power can acquire religious legitimation. Divine sanction of competition - 'we see the truth more clearly and accurately than you' - is the final seal and establishes the conditions for unfettered misuse of power in the supposed interests of a higher good. Under such conditions the well-worn phrase 'the ends justify the means' can become a frightening tool of self-delusion. In fact for the people of the Gospel of Jesus, the ends never justify the means; rather the ends determine the means. If the end is the Gospel of the God and the coming Kingdom,

2. Goleman, Working with Emotional Intelligence, p. 199.

3. See Raimo Tuomela, The Philosophy of Sociality: The Shared Point of View (Oxford: Oxford University Press, 2007), pp. 149-81 (150). 
then the character of this God determines how we shall live with each other in the present.

Perhaps the Church's calling is to exemplify a new kind of 'spiritual intelligence' (1 Cor. 2.16). It is hard to square this claim with some of the ways, in which Christians actually behave towards one another. Yet the apostle Paul calls the Church to a higher place with an expectation that the mind of Christ would be prized above all things. This means that the particular vocation of the Church is to live out of and continually strive to live into the mind of Christ. None of us see it all with absolute clarity; none of us is smarter than all of us. Most importantly, we all need each other in order to catch a fuller glimpse of the 'bright mystery' of faith. ${ }^{4}$ And we all have a problem with the blindness that results from wood in the wrong place (Lk. 6.41).

This was brought home to me sharply and powerfully at Lambeth in the address by Chief Rabbi Sir Jonathan Sacks. At the conclusion of his remarkable address he took questions. Someone said: 'tell us about Jesus'. Sacks was not short for words and took us back to the Jewish day of atonement and then spoke of Jesus' prayer, 'Father forgive them for they know not what they do'. The Jesus he spoke of was the one whose heart still uttered that prayer. It was unmistakable for me that this prayer of Jesus was for our own Communion. So many conflicts, so many positions of assumed rightness, so many fractures and here is a prayer from the heart of Christ. We think we know what we're doing but we don't, at least not in God's eyes. We all sit under God's judgment and in our own judgments. As members of the Body of Christ, perhaps we need to think more carefully about the ecclesial dimension of spiritual and emotional intelligence. Do we have criteria that might assist us?

\section{Criteria for Ecclesial Intelligence: Fundamentals and Non-fundamentals}

Anglicans have invested significant energy over the course of history searching for and clarifying the criteria for assessing ecclesial intelligence. Usually, in periods of great crisis, some of the most perceptive and long-lasting criteria have emerged. The conflicts and struggles in the Church of England in the sixteenth and seventeenth century are an interesting case in point. Internal conflicts over the shape and character of the Church occupied the energy of many theologians in the early decades of the seventeenth century. Providing a reasoned apology for the English Church in relation to Roman claims generated

4. Daniel Hardy, God's Ways with the World: Thinking and Practicing Christian Faith (Edinburgh: T \& T Clark, 1996), pp. 17-19. 
a literature on the idea of the fundamentals of Christianity, which became important in handling conflict. ${ }^{5}$

Some things were so fundamental that to reject them was to fall into heresy. Other matters of belief and practice were not so critical for being a Christian. When in the late sixteenth century Richard Hooker appealed to the distinction between fundamentals and nonfundamentals ('accessories'), his purpose was to show that the Church of Rome, whilst an 'unsound' church, nevertheless remained a church. ${ }^{6}$ There was wisdom in his approach and it has informed a great deal of Anglican self-understanding ever since. In the work of the early seventeenth century ecclesiologist, Richard Field (1561-1616), the appeal to certain fundamentals belonged to his irenic ecumenical theology. For Field - of Calvinist sympathies - it was possible to be 'of the Church' at various levels. ${ }^{7}$

In the early decades of the seventeenth century, the new situation was the rise of Puritanism and the influence of Separatism. In this context, the appeal to the familiar Anglican apologetic regarding the distinction between fundamentals and non-fundamentals was always threatening to collapse; the list of fundamentals seemed rubbery with a tendency to expand. The Anglican apologist William Chillingworth (1604-1644) argued that a complete list of what was deemed fundamental for a person's salvation was impossible. ${ }^{8}$ He stressed the requirement of a heart open to God. The matter of what was necessary to be believed was an inherently contentious matter.

The seventeenth century Bishop Stillingfleet (1635-1699) did a great service to all when he drew an important distinction between (a) those things necessary to be believed by an individual for Salvation and (b) those things 'necessary to be owned in order to Salvation, by Christian societies, or as the bonds and Conditions of Ecclesial Communion'. ${ }^{9}$ He stated that 'The want of understanding this distinction of the necessity of things, hath caused most of the perplexities and Confusion in this Controversy of Fundamentals' ${ }^{10}$ Amidst the turmoil of his

5. See Stephen Sykes, 'The Fundamentals of Christianity', in Stephen Sykes and John Booty (eds.), The Study of Anglicanism (London: SPCK, 1988), pp. 231-45.

6. See Paul Avis, Anglicanism and the Christian Church (Edinburgh: T \& T Clark, 1989), pp. 49, 50.

7. Avis, Anglicanism and the Christian Church, pp. 68-72.

8. Sykes, 'The Fundamentals of Christianity', pp. 237, 238.

9. Edward Stillingfleet, A Rational Account of the Grounds of the Protestant Religion (1664), The Works, 6 Vols. (London 1709), vol. IV, p. 48.

10. Ibid. 
own day, Stillingfleet offered some wise counsel for the making of an intelligent Church. Our present turmoil belongs to a longer history of reflection and controversy on what it is that makes for the being of the Church and the nature of the authority that determines the matter.

\title{
Three Contemporary Criteria: Intensity, Extent and Substance
}

In the course of the work of the Inter-Anglican Theological and Doctrinal Commission (IATDC), three criteria were proposed to assist in the theological controversy surrounding the matter of same-sex unions and the consecration of a priest as a bishop in a same-sex relationship. The criteria were first 'floated' in October 2003.

\begin{abstract}
A problem arises over innovations about which there are different views in the Church concerning the relative weight or significance to be accorded to a matter. Such are the matters in question. How ought the Church to proceed in such situations? A principle here might be that if the dispute is: intense (e.g. generates high degree of sustained and unresolved debate that threatens the unity of the Anglican Communion; or that requires urgent attention), extensive (e.g. not confined to one section or region of the Church; has significant implications for mission and ecumenical relations; has a wider social impact) and substantial (concerning an actual issue, and not for example, simply being generated by the media), then the matter cannot remain simply for the local Church (e.g. the diocese) to handle. ${ }^{11}$
\end{abstract}

The final report in 2008 stated; 'To clarify when some communion-wide decision is to be made, we have introduced the criteria of intensity, substance and extent: the more these characteristics feature in a controversy, the wider the scope for a ministry of mutual admonition'. ${ }^{12}$

There are echoes here of the ancient threefold test of Catholicity espoused by St Vincent of Lerins in the fifth century: 'what has been believed everywhere, always and by all'. The appeal to ecumenicity, antiquity and consent was intended to enable the Church to differentiate true from false tradition. Of course, we should not be surprised to find that the application of this triple criteria was quite controversial. On the other hand, it did offer a framework within which a controversy regarding the faith could be interrogated theologically. So it is with the triple appeal to intensity, extent and substance; not a failsafe mechanism for dispute-solving but a framework for responsible

11. See 'Reflections offered to the Primates of the Anglican Communion, October 2003', para. 21. Posted at www.anglicancommunion.org

12. IATDC, p. 45. 
theological engagement. This has been something remarkably lacking in so much of the controversy in the Anglican Communion in recent years. The IATDC criteria may provide a complimentary yet related set of criteria to the more familiar Anglican 'fundamental/nonfundamental' approach. It is a matter that requires further theological testing. The criteria in view have not been totally lost in the present turmoils. ${ }^{13}$

The development and testing of theological criteria is not an end in itself, but is directed to the enhancement of the spiritual intelligence of the body of Jesus Christ. Are we an intelligent Communion? Part of the answer might involve demonstrating a commitment to finding ways and means to conduct wise theological debate, which values good quality rules and a clear framework for engagement.

\section{Three Criteria from Lambeth 2008}

The essays reflecting on Lambeth in the present volume of the Journal each offer a perspective on the character of a Church, which is faithful to the Gospel of Jesus Christ. In one sense, the essays present criteria to test the Church's unity, holiness, catholicity and apostolicity. The essays point to fundamental claims made upon the Communion by virtue of it being the body of Christ. Indeed what is offered is more than formal criteria for engagement with each other and the world. Rather our authors present the reader with concrete proposals regarding the way a Church should live Christianly. Are these things apparent? Do they make a difference? Perhaps we might say they are performative criteria rather than theoretical. In this sense, our authors provide another angle on the Anglican body; another way of testing its ecclesial intelligence.

\section{A Praying Church}

Bishop Geralyn Wolf offers an important reminder that a critical barometer of ecclesial health and spiritual acuity will be its prayer. A communion is brought into conformity with the will of God as it joins

13. Archbishop Rowan referred to the criteria in his Communion, Covenant and our Anglican Future, Monday 27 July 2009, Reflections on the Episcopal Church's 2009 General Convention from the Archbishop of Canterbury for the Bishops, Clergy and Faithful of the Anglican Communion, para. 13. Posted at http:// www.archbishopofcanterbury.org/2502?q=reflections+on+the+episcopal+church. Bishop Tom Wright has reminded the Church of the same and more recently the Anglican Communion Institute has recognized their importance. 
in the high priestly prayer of Jesus. Prayerful longing in this tradition is not a recipe for disengagement; rather precisely amidst the turmoil and 'feeling of spiritual disequilibrium' Wolf holds the church to Jesus' prayer. Such prayer is the mark, argues Wolf following Michael Ramsey, of a Church which lives with 'a many-sided wholeness'. It is the fervent language of prayer that holds the babble of languages that divide and disturb the church. In the light of Lambeth, Wolf speaks of a church learning to live 'in the throws of Good Friday and Holy Saturday'. The paschal mystery has a hard edge to it. It can lead us into a breach of fellowship, which is painful. Wolf's reflections do not leave us in a comfortable place but a place in which and from which resurrection hope can spring.

Bishop Peter Lee reflects on the experience of Indaba. He explores Indaba as an activity of obedient listening, and to my mind it offers a way to enter into the high priestly prayer of Jesus. Prayer and listening are so closely interwoven; both require work; both involve bearing one another's pain; both require honesty and openness. Indaba listening requires that 'every bishop's voice must be heard', which is never an easy matter to accomplish, especially as Lee reminds us 'Europeans have watches and Africans have time'. Lee observes that Indaba 'fits into a context where the value of the human being outweighs convenience, haste, and the pursuit of personal opinions and sectional agendas'. Lee also reminds us that when different voices are heard the real clash of opinions and barely concealed prejudices come to the fore. It is inevitable and disturbing. If passionate differences are the mark of our life as a Communion, Lee also reminds us that it is the fractured mosaic of English Christianity that has been exported worldwide'. There can be no cheap reconciliation and learning 'to accept each other as Christ accepted us... and working to form all of us into a loving and functional body' is for Lee 'the shape of Indaba obedience'.

\section{A Learning Church}

Karl Barth once said, 'study without prayer is blind and prayer without study is empty'. It has always stuck with me. A praying church has to be a church learning wisdom. Bishop Tom Wright strikes a characteristic Anglican note in his discussion of a 'ScriptureFormed Communion'. Learning the way of wisdom takes us into Scripture. Wright is clear and insistent that the 'question of authority, use and relevance of scripture in today's Anglican Communion needs to be addressed more thoroughly'. His essay makes a case why this is necessarily so and what the dangers are if we weaken in our resolve 
on this matter. Wright wants us to get 'beyond that sterile stand-off between traditional positions' on Scripture. He encourages the reader to move beyond 'prooftexts' to 'paradigms'; learning to live as a new creation with a gospel ethic of the coming Kingdom; taking more seriously the new covenant. Importantly Wright notes that 'to address the problems we now face, we need a church steeped for many generations in a wise and mature reading of Scripture, and this is precisely what we haven't got'. Wright invites, indeed insists on a much more vigorous and serious engagement with the whole of Scripture. Only in this way can we be an intelligent Communion at prayer.

Bishop Ande Titre calls us back to the centre of faith and hope in Scripture, Jesus Christ. Titre is unapologetic, 'the question the Communion is facing is: Who is Jesus Christ for Anglicans?' It was the question posed to Titre by the Congolese immigration officer when the bishop returned home from Lambeth. Titre opens up the question of Christology from an African perspective arguing that it should no longer be possible to do Christian theology today without taking into account the reflections and insights of Africans concerning Jesus Christ'. Titre's paper shows why this is the case as he discusses 'African holistic Christology', Jesus the Lord of cultures, Jesus the healer and liberator. For Titre, Christology is the centre of faith for it unfolds the way of transformation and hope and reveals the deepest wisdom.

Can this wisdom be translated into an ecclesial wisdom? Archbishop Jeffrey Driver turns his attention to this theme and argues that the way ahead in faith requires a recovery of an Anglican 'polity of persuasion'. Driver charts the course of Anglicanism from the first Lambeth conference and highlights key Anglican traits. In this respect he discusses the emphasis on the local - dispersed authority, commitment to inculturation - and notes how it can also lead to paralysis. One response is to 'strengthen the centre', a theme that featured at the Global Anglican Futures Conference in 2008. However, Anglican wariness about centralization means it is committed at its heart to a polity of persuasion. Driver develops the marks of such a polity: creative conflict in community, commitment to time and patience, seeking quality engagements. His ecclesial reflection on the state of the Communion post Lambeth dovetails with Titre's Christology and Wright's scripture hermeneutic. A polity of persuasion takes its cue from the Jesus of the gospels. It is a polity that eschews the misuse of power. Driver leaves us with Jesus' words to his disciples; 'It shall not be so among you'. Divine wisdom is found through service not domination. This is a hard lesson to learn. 


\section{A Serving Church}

The final three essays point the Anglican Church beyond itself into the world for which Christ died and rose again. An intelligent Communion does not live for itself but others; moreover, it only finds the secret of its own wisdom through an ecclesial self-forgetfulness. Bishop Michael Doe reminds us that the movement outwards in mission has historically brought both blessing and problems. He calls attention to the importance of inter-dependence as a way of overcoming older colonial mentalities; a more generous sharing of resources that breaks the consumerist packaged donor model; and he ends with a warning about the new forms of colonialism apparent in new alliances between north and south. It requires both wisdom and courage to serve the neighbour.

Professor Renta Nishihara, a Lambeth participant, offers an insight into the Anglican Church in Japan (Nippon Sei Ko Kai). This church celebrates its 150th anniversary in 2009. This missionary church appears to embody a wide variety of Anglican Christianity. However, its mission has to be undertaken in a country where Christians represent less than 1\% of the population. The Anglican Church is numerically tiny but its influence is much greater through its missionary service via schools, hospitals and welfare. Unity is critical in order to undertake the mission with integrity in such a context. This leads to a certain puzzlement among our Japanese brothers and sisters about the need for a covenant beyond the Lambeth Quadrilateral. Nishihara reminds an anxious Church that repentance confession of sins and forgiveness is a mark of a discipleship that is spiritually intelligent. It is a matter close to the heart of the Japanese and there is great wisdom to learn from this mission church.

Bishop Trevor Mwamba states that the bishop's 'finest hour at Lambeth Conference 2008 was marching through Whitehall and Westminster in solidarity with the world's poorest people'. Not the 'luxury' of human sexuality but poverty, HIV and AIDS, malaria, bad governance, unjust trade policies, environment; when such matters occupy centre stage of the Anglican Church then it will be an intelligent Communion. Mwamba speaks out of an African context of death and violence. The Millennium Development goals are precisely where the energies of the Communion ought to be directed. Mwamba shows how relevant such goals are to his homeland of Botswana. It puts the debates of the Communion in context and, given the shift in world Anglicanism to the south, Mwamba's paper is a salutary note to end the bishops' reflections on Lambeth 2008. 
Conclusion: Praying, Learning and Serving

The essays in this volume offer a rich tapestry of Anglican faith and service. They make their own contribution to the ongoing discussion of those criteria by which a world-wide Church grapples with its own life and calling. Amidst our turmoils and struggles, there is the upward call of Christ beyond ecclesial self-absorption into the world of need and longing. Within the ecology of ecclesial existence, our essayists point us to the Triune God who calls us deeper into prayer and holy learning that we might serve the world where Christ awaits us. In doing so, they provide key markers for a spiritually intelligent Communion. To this extent, they represent a stronger and more assured Lambeth pulse. 